K. Nesterenko, S. Rahulin, I. Syroizhka, O. Dmitriev, N. Zhivitsky, A. Sharabaiko

Flight Academy of the National Aviation University, Kropivnitsky, Ukraine

\title{
THE APPLICATION OF INFORMATION TECHNOLOGIES DURING MAINTENANCE TO ENSURE THE RELIABILITY OF THE OPERATION OF AVIATION EQUIPMENT
}

\begin{abstract}
During the operation of aviation equipment, is carried out a set of works concerning the support and renewal of its serviceability and efficient condition, if necessary and possible. These tasks are solved with the help of information systems during aviation equipment maintenance. If necessary and possible, during the aviation equipment operation, is carried out a work package concerning the support and renewal, of its operative and serviceable condition. These tasks are solved with the help of IT solutions during the aviation equipment maintenance. Aircraft maintenance is an important component of the aviation system which ensures the functioning of aviation throughout the world. Insofar as the air traffic performance grows, and the tough requirements for maintaining the schedule of commercial flights necessitate the need to increase the intensity of aircraft usage. Also is continued the toughening of requirements for the timeliness of maintenance.
\end{abstract}

Keywords: information systems aviation equipment maintenance.

\section{Introduction}

The quality of maintenance as a reliability factor of aviation equipment operation. Maintenance is a work package (set of operations) which is carried out on aviation equipment during preflight and post flight preparation, storage and transportation in order to maintain its serviceability and operability. Maintenance products are not any new products but performed tasks as foreseen in the production assignment.

Maintenance quality reflects the labor quality of engineering and technical personnel of aircraft maintenance facility [1]. The first-priority target of the quality system is to provide a maintenance organization with guaranteed opportunity to produce foolproof products.

In order to estimate the completeness of the scope and work performance technology compliance provided by the performers and which are foreseen by the maintenance tasks, and also to compare the results of the various operators and staff members work with the established standards necessary for justification of procedures which are targeted at quality improvement and efficiency assessment are introduced maintenance quality indicators.

The quality of maintenance is provided by technological equipment, and the organization of the process using IT systems, which must comply with the Rules approved by the competent maintenance organizations [2].

Thereafter, verification of tools and equipment requires from the organization an approved procedure for regular inspections and maintenance. It also requires an accurate marking system of all tools and equipment that were added to a database in the form of information stating when should be carried out the next inspection, maintenance or calibration, and whether the tool and equipment are unserviceable for any reason, if this is not obvious.

Periodic inspections, maintenance or calibration must comply with the manufacturer's instructions. With this background, it is officially stated that the standard defines the following rules for establishment of a state institutions and have a legal force and are applied in the air transport field [3]. The quality of the operator's work is assessed by the degree of compliance with the task assigned to each completed work and the requirements of the operational documentation. Incomplete performance of the task (scope of work), troubleshooting failure in case of defect, performance of work with a violation of technology is considered to be a faulty production.

The insufficiency of maintenance is also evidenced by failures and malfunctions detected in flight, which are recorded by the on-board monitoring systems, and if they were the result of maintenance violations.

The main groups of factors that have an exert decisive influence on the quality of maintenance personnel work are shown in Fig. 1 [4].

At the present time, a number of methods and models have been developed. These methods and models describe the maintenance processes, in particular, on the basis of semi-Markov processes with a finite set of states [5], the generalized structured method [6], the use of game theory [7], the construction and analysis of cause-effect trees [8], situations assessment tree graphs [9].

However, all existing methods and indicators for assessing the maintenance quality, taking into account the activities of the maintenance personnel, are directly connected with the assessment of the aircraft reliability in flight, depending on the quality of maintenance operations or with the assessment of the aircraft maintenance quality, taking into account possible operator errors.

In a reference book [10], the investigation of the aircraft reliability is confined to the consideration of the aircraft reliability, taking into account the activities of the maintenance personnel.

If we assume that the probability of simultaneous occurrence of two or more errors is negligible and that each error can be almost instantly compensated with probability $P_{e c}$, then the probability of aircraft failurefree operation during the time $\left[t_{l}, t_{l}+\Delta t\right]$ will be determined by expression:

$$
\begin{gathered}
P_{f}\left(t_{1}, \Delta t\right)= \\
=P_{t c}\left(t_{1}, \Delta t\right)\left\{P_{m p}(\Delta t)+\left[1-P_{m p}(\Delta t)\right] P_{e c}\right\},
\end{gathered}
$$




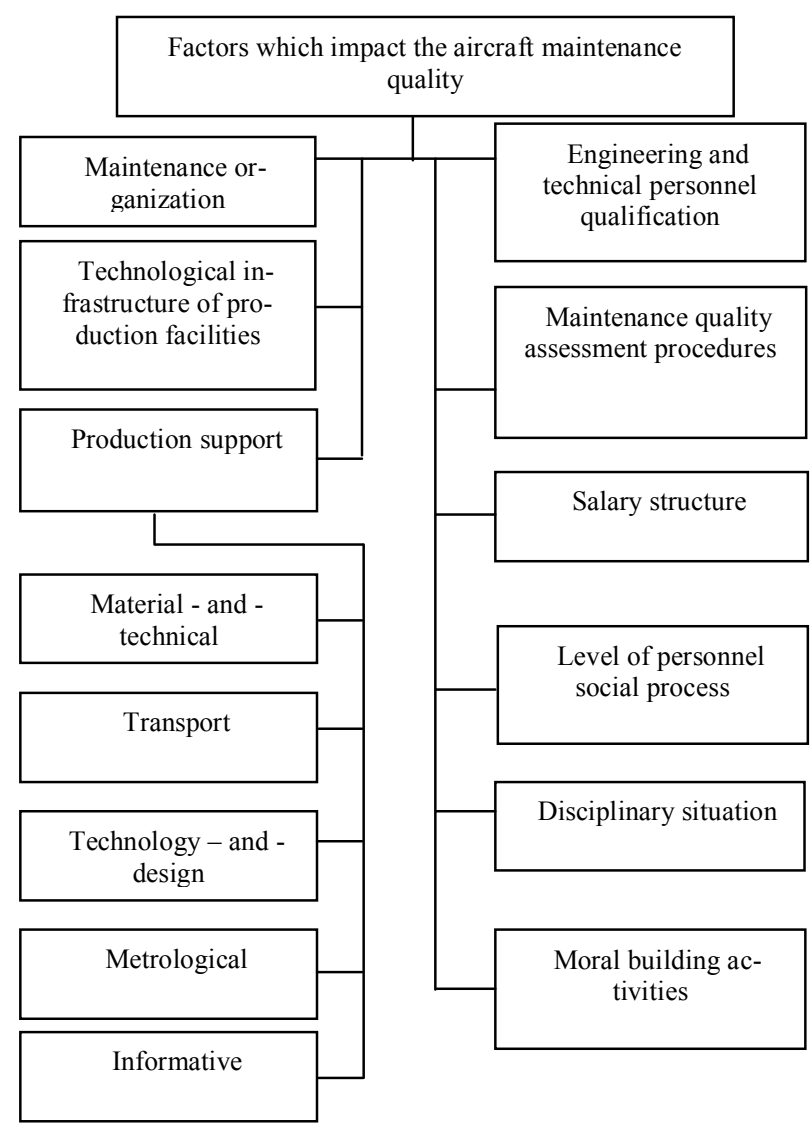

Fig. 1. Factors which define the aircraft maintenance quality

where $P_{t c}(t, \Delta t)$ - the probability of aircraft failure-free operation during the time $\left[t_{l}, t_{I}+\Delta t\right] ; P_{m p}(\Delta t)$ - probability of trouble-free operation of maintenance personnel over a period of time $\Delta t$ upon condition that the aircraft is operating without no failures.

Compensation for technological errors is an important way to improve the reliability of aircraft. Therein, the probability of aircraft failure-free operation during the time $\left[t_{l}, t_{l}+\Delta t\right]$

$$
\begin{gathered}
P_{t c}\left(t_{I}, \Delta t\right)=P_{m p}\left(t_{I}, \Delta t\right) \times \\
\times\left\{P_{t c}(\Delta t)+\left[1-P_{t c}(\Delta t)\right] P_{t . c .}\left(t_{I}, \delta, t_{I}+\Delta t\right)\right\},
\end{gathered}
$$

where $P_{t . c .}\left(t_{l}, \delta, t_{l}+\Delta t\right)$ - conditional probability of failure-free operation during time $\left[t_{l}, t_{l}+\Delta t\right]$ of aircraft with compensation for the consequences of technical condition failures upon condition that at a moment $\delta$ there was a failure and it was compensated $\left(t_{1}<\delta<t_{1}+\Delta t\right)$. The evaluation of the aircraft maintenance quality, taking into account the significance of the possible consequences of operator errors, was considered in collection of research papers [11]. In the conditions of the airlines, the quality management system of maintenance for assessing the quality of the operators' work, is used a generalized quality factor $K_{g}^{o}[12]$. It is defined by summing-up base coefficient, and coefficients of its increase $K_{i}$ and decrease $K_{d}$ [12]:

$$
K_{g}^{o}=A+\sum_{i=1}^{n_{i}} n_{i} \cdot K_{i}-\sum_{j=1}^{n_{j}} n_{j} \cdot K_{d},
$$

where A - base coefficient $(A=100) ; n_{i}, n_{j}$ - incidents count according to top performance and violations.

With reference to the foregoing, it can be concluded that all known and partially considered, in the performance, maintenance quality indicators cannot act as a reliable estimate of carried out maintenance and, therefore, to ensure reliability in operation. Special attention is paid to this factor when analyzing the maintenance of the trainer aircraft fleet, where, as such, efficiency is transformed into other equipment usage assessments with unchanged requirements for reliability.

\section{Factors affecting the efficiency of aircraft usage in civil aviation}

It is known that one of the ways to increase the efficiency of aircraft usage is to reduce all types of downtime. A key factor is the introduction of IT technologies at all stages of the aircraft life cycle.

Since the number of serviceable, ready-to-fly aircraft is characterized by the serviceability indicator $K_{\text {ser }}$, which is the ratio of the time during which the aircraft is in serviceable condition to the annual worktime fund (as \%):

$$
K_{\text {ser }}=\frac{8760-T_{m}}{8760} \cdot 100 .
$$

The values of the aircraft serviceability coefficients vary depending on the aircraft type. The more aircraft maintenance and repair downtime $\left(T_{m}\right)$, the smaller the $K_{\text {ser }}$, and consequently the less the annual flying rate.

The aircraft maintenance and repair downtime is determined by such factors as the aircraft equipment reliability, operational and repair technology, the level of mechanization and production processes automation, applied information complexes for maintenance and repair, the development of production technology, the ergonomics of aircraft and their airborne equipment as maintenance and repair objects, etc.

Improvement of these factors contributes to the further development of production.

An analysis of the available data shows that with the increasing complexity of the aircraft design and airborne equipment, there also increase losses, due to their down time. The increase of aircraft downtime costs forces to carry out a research related to the increase of their usage efficiency $[13,14]$.

In Fig. 2 Factors affecting the efficiency of aircraft usage are shown. To increase the aircraft annual flying rate and, consequently, the efficiency of their usage, it is necessary:

- improve reliability, ergonomics, aircraft maintenance and repair efficiency and their onboard equipment, manage their life time, reduce the amount of maintenance and repair works, from a perspective of aviation ergonomics;

- implement more advanced methods and strategies for maintenance and repair;

- to mechanize and automate production processes, to make wider use of mobile integrated information and maintenance systems that would correspond to the principles of human-centered automation; 


\begin{tabular}{|c|c|}
\hline Aircraft usage efficiency & \\
\hline \multicolumn{2}{|l|}{$\downarrow$} \\
\hline \multicolumn{2}{|l|}{ Factors affecting the efficiency of aircraft usage } \\
\hline $\begin{array}{l}\text { Flight and engineering and technical personnel } \\
\text { refresh training }\end{array}$ & $\begin{array}{l}\text { Application computers in aircraft maintenance } \\
\text { facilities and airports }\end{array}$ \\
\hline $\begin{array}{l}\text { Aircraft maintenance } \\
\text { organization improvement }\end{array}$ & $\begin{array}{l}\text { Mechanization and automation of maintenance produc- } \\
\text { tion processes }\end{array}$ \\
\hline $\begin{array}{l}\text { Change in the scheduled } \\
\text { flights minimum }\end{array}$ & $\begin{array}{c}\text { Automatic control } \\
\text { of systems and devices }\end{array}$ \\
\hline $\begin{array}{l}\text { Reduction of working time for aircraft line } \\
\text { maintenance checks }\end{array}$ & $\begin{array}{l}\text { Implementation of the on-condition } \\
\text { maintenance system }\end{array}$ \\
\hline $\begin{array}{l}\text { Mechanization and automation } \\
\text { of operations at airports }\end{array}$ & $\begin{array}{c}\text { Maintenance } \\
\text { diagnostics }\end{array}$ \\
\hline $\begin{array}{l}\text { Automation of aircraft take-offs } \\
\text { and landings }\end{array}$ & $\begin{array}{l}\text { Testability of assemblies, } \\
\text { units, devices }\end{array}$ \\
\hline $\begin{array}{l}\text { Application of on-board } \\
\text { computers }\end{array}$ & $\begin{array}{l}\text { Aircraft } \\
\text { maintainability }\end{array}$ \\
\hline
\end{tabular}

Fig. 2. Factors affecting the efficiency of aircraft usage

- equipping with the automated test set of the technical condition of aircraft engines and all critical systems;

- to improve the maintenance and repair organization patterns, the recruitment and staffing of maintenance work crew of aircraft, production facilities and maintenance personnel employment terms;

- increase the usage of night time;

- avoid night aircraft downtime at intermediate and terminal airports by rational scheduling;

- usage of automatic landing approach, which allows to fly in any meteorological conditions.

\section{Conclusions}

Among abovementioned factors and costs, an important place is occupied by the problems of aircraft maintenance. So the specific weight of the costs for aircraft maintenance is $17 \%$ of the total cost of their operation. A major part in improving the efficiency of aircraft usage is currently played by the improvement, automation of maintenance systems, and the training systems for aircraft maintenance operators, which are achieved through the implementation of IT technologies in the maintenance and repair system.

\section{REFERENCES}

1. Rekomendatsiya po sovershenstvovaniyu sistemy upravleniya kachestvom tekhnicheskogo obsluzhivaniya aviatsionnoy tekhniki $v$ ATB grazhdanskoy aviatsii [Recommendation on the improvement of the quality management system for aviation equipment maintenance at maintenance facility in the Civil Aviation]. Moscow: Vozdushnyy transport, 1986, p. 48 (in Russian)

2. Order no. $209 \mathrm{dd}$ April $20^{\text {th }}, 2010$ Pro zatverdzhennia Pravyl skhvalennia orhanizatsii z tekhnichnoho obsluhovuvannia (Part145) ta zatverdzhennia Zmin do Pravyl sertyfikatsii orhanizatsii z tekhnichnoho obsluhovuvannia aviatsiinoi tekhniky [About approval of "Maintenance Organization Approvals" (Part-145) and approval of changes to the Rules of Aircraft Maintenance Organizations Certification], K: Ministry of Transport and Communications of Ukraine, 2010, p. 14 (in Ukrainian)

3. Metodychni rekomendatsii shchodo pryiniatnykh metodiv vstanovlennia vidpovidnosti ta kerivnyi material (AMC\&GM) do Pravyl skhvalennia z tekhnichnoho obsluhovuvannia (Part-145) [Guidelines for Acceptable means of Compliance and Guidance material (AMC \& GM) to Part-145 Maintenance Organization Approvals], 2011, K, p. 129 (in Ukrainian)

4. Smirnova N. N., Vladimirov N.I., Chernenko Zh.S., eds Smirnova N. N. (1990) Tekhnicheskaya ekspluatatsiya letatelnykh apparatov [Lifting vehicles maintenance]. Moscow: Transport, p. 423 (in Russian)

5. Kashtanov V.A. (1984) Polumarkovskie modeli protsessa tekhnicheskogo obsluzhivaniya [Semi-Markov models of maintenance process]. Moscow: Znanie, p. 423 (in Russian)

6. Gubinskiy A. I. (1982) Nadezhnost $i$ kachestvo funktsionirovaniya ergaticheskikh sistem [Reliability and quality of ergatic systems functioning]. Leningrad: Nauka, p. 269 (in Russian)

7. Venda V.F. (1975) Inzhenernaya psikhologiya i sintez sistem otobrazheniya informatsii [Engineering psychology and synthesis of information display systems]. Moscow: Mashinostroenie, p. 396 (in Russian)

8. Galaktionov A.I. (1978) Osnovy inzhenerno-psikhologicheskogo proektirovaniya ASU TP [Fundamentals of engineeringpsychological project]. Moscow: Energiya, p. 160 (in Russian)

9. Shibanov G.P. (1983) Kolichestvennaya otsenka deyatelnosti cheloveka v sistemakh chelovek, tekhnika [Quantitative assessment of human activities in systems human, technology]. Moscow: Mashinostroenie, p. 263 (in Russian) 
10. Editors: Avduevskiy V. S., et al. (1986) Nadezhnost i effektivnost v tekhnike [Reliability and efficiency in engineering]. Reference book in 10 vol., Moscow: Mashinostroenie, vol. 1 Metodologiya. Organizatsiya. Terminologiya [Methodology. Organization. Terminology] eds Rembezy A. I., p. 223 (in Russian)

11. Коваленко А.А. Сучасний стан та тенденції розвитку комп'ютерних систем об'єктів критичного застосування / А.А. Коваленко, Г.А. Кучук // Системи управління, навігації та зв’язку. - Полтава . ПНТУ, 2018. - Вип. 1(47). - С. 110-113.

12. Smirnov N. N, Mulkidzhanov I.K. (1972) Ekspluatatsionnaya tekhnologichnost transportnykh samoletov [Operational technology of transport aircraft]. Moscow: Transport, p. 208 (in Russian)

13. Kuchuk G., Kovalenko A., Kharchenko V., Shamraev A., "Resource-oriented approaches to implementation of traffic control technologies in safety-critical I\&C systems" in book: Green IT Engineering: Components Network and Systems Implementation, Springer International Publishing, vol. 105, pp. 313-338, 2017.

14. Savenkov M.V., Zakirov R.A. Inzhenerno-tekhnicheskoe obespechenie avtomatizirovannykh sistem upravleniya $v$ aviatsii [Engineering support of automated control systems in aviation]. Moscow: Mashinostroenie, p. 272 (in Russian)

Рецензент: д-р техн. наук, проф. І. В. Шостак, Національний аерокосмічний університет імені М. Є. Жуковського «ХАІ», Харків Received (Надійшла) 17.11.2018 Accepted for publication (Прийнята до друку) 16.01.2019

\section{Применение информационных технологий при техническом обслуживании для обеспечения надежности работы авиационной техники}

Е. С. Нестеренко, С. В. Рагулин, И. О. Сыроежка, О. Н. Дмитриев, Н. Г. Живицкий, А. Н. Шарабайко

В ходе эксплуатации авиационной техники проводится комплекс работ по поддержке и восстановлению ее исправности и работоспособного состояния, если это необходимо и возможно. Эти задачи решаются с помощью информационных систем при обслуживании авиационной техники. При необходимости и возможности во время эксплуатации авиационной техники выполняется комплекс работ по поддержке и восстановлению ее исправного и исправного состояния. Эти задачи решаются с помощью ІТ-решений при обслуживании авиационной техники. Техническое обслуживание самолетов является важной составляющей авиационной системы, которая обеспечивает функционирование авиации во всем мире. Поскольку производительность воздушного движения растет, а жесткие требования к соблюдению графика коммерческих рейсов обуславливают необходимость увеличения интенсивности использования воздушных судов. Также продолжается ужесточение требований к своевременности технического обслуживания. Техническое обслуживание это комплекс работ (набор операций), который выполняется на авиационном оборудовании во время предполетной и послеполетной подготовки, хранения и транспортировки с целью поддержания его работоспособности и работоспособности. Продукты для технического обслуживания - это не новые продукты, а выполняемые задачи, предусмотренные в производственном задании.Качество технического обслуживания отражает качество труда инженерно-технического персонала авиационно-технического обслуживания объекта. Первоочередная задача системы качества - предоставить организации по техническому обслуживанию гарантированную возможность производства надежных изделий. Для оценки полноты соответствия объема и технологии выполнения работ, предоставленных исполнителями и предусмотренных задачами технического обслуживания, а также для сравнения результатов работы различных операторов и сотрудников с установленными стандартами, необходимыми для обоснования процедур которые направлены на улучшение качества и оценку эффективности, вводятся показатели качества обслуживания. Качество обслуживания обеспечивается технологическим оборудованием и организацией процесса с использованием IT-систем, которые должны соответствовать правилам, утвержденным компетентными организациями по техническому обслуживанию.

Ключевы е слов а: информационные системы обслуживания авиационной техники.

\section{Застосування інформаційних технологій під час технічного обслуговування з метою забезпечення надійності експлуатації авіаційної техніки}

\section{К. С. Нестеренко, С. В. Рагулін, І. О. Сироїжка, О. М. Дмитрієв, М. Г. Живицький, О. М. Шарабайко}

У ході експлуатації авіаційної техніки проводиться комплекс робіт за підтримкою і відновленням ії коректності і працездатного стану, якщо це необхідно і можливо. Ці задачі вирішуються за допомогою інформаційних систем при обслуговуванні авіаційної техніки. При необхідності і можливості під час експлуатації авіаційної техніки виконується комплекс робіт за підтримки і відновлення її виправданого і виправданого стану. Задачі реєстрації з використанням ITрішень при обслуговуванні авіаційної техніки. Технічне обслуговування літаків $\epsilon$ важливою складовою авіаційної системи, яка забезпечує функціонування авіації у всьому світі. У цілому продуктивність повітряного руху зростає, а жорсткі вимоги до серйозної графіки промислових рейсів обумовлюють необхідність збільшення інтенсивності використання повітряних судів. Також продовжується вживання вимог до своєчасного технічного обслуговування. Технічне обслуговування - це комплекс робіт (наборів операцій), який виконується на авіаційному обладнанні під час попередньої і післяопераційної підготовки, зберігання та транспортування з метою підтримки його працездатності. Продукти для технічного обслуговування - це не нові продукти, які виконуються завдання, передбачені в виробничому завданні. Якість технічного обслуговування відображає якості праці інженерно-технічного персоналу авіаційно-технічного обслуговування об'єкта. Першочергова задача системи якості - надавати організації по технічному обслуговуванню гарантовану можливість виробництва надійних виробів. Для оцінки повноти відповідності об'єму і технологіям виконання робіт, наданих виконавцям і передбаченим завданням технічного обслуговування, а також для порівняння результатів роботи різних операторів і співробітників з встановленими стандартами, необхідними для покращення процедури та оцінки ефективності. Якість обслуговування забезпечується технологічним обладнанням і організацією процесу з використанням ITсистем, які повинні відповідати правилам, затвердженим компетентними організаціями за технічним обслуговуванням.

Ключов і слов а - інформаційні системи обслуговування авіаційної техніки. 